\title{
Characterization of a New Nepovirus Causing a Leaf Mottling Disease in Petunia hybrida
}

Sara Bratsch and Benham Lockhart, Department of Plant Pathology, University of Minnesota, St. Paul, MN; and Dimitre Mollov, USDAARS, National Germplasm Resources Laboratory, Beltsville, MD

\begin{abstract}
Icosahedral virus-like particles were isolated from Petunia hybrida cuttings with interveinal chlorotic mottling. The virus was transmitted by mechanical inoculation from infected to healthy $P$. hybrida, and was found to contain a bipartite RNA genome of 7.6 and 3.8 kilobases. Full genomic sequence was obtained by high-throughput sequencing combined with RACE amplification of the $5^{\prime}$-termini of RNAs 1 and 2, and reverse-

transcription PCR amplification of the 3'-termini with oligo-dT and sequence specific primers. Based on particle morphology, genome organization, and phylogenetic analyses, it was concluded that the new virus is a member of the genus Nepovirus, subgroup A. This new virus causing a leaf mottling disease of petunia was provisionally named Petunia chlorotic mottle virus (PCMoV).
\end{abstract}

Petunia hybrida, commonly called the garden petunia, is the most popular annual bedding plant worldwide, and is valued for prolific, large, and colorful flowers (Bombarely et al. 2016). In 2015, the wholesale value of petunia plants exceeded $\$ 135$ million in the United States (2015 USDA Floriculture Crops Summary). Petunias are also used as a genetic model (van der Krol and Immink 2016). They are members of the family Solanaceae and wild species are native to South America from Argentina to Uruguay, Southern Brazil, and the foothills of the Andes (Wijsman 1982). In the early 1800s, petunias were imported to Europe and crosses between the wild $P$. axillaris and $P$. inflate yielded the colorful $P$. hybrida (Wijsman 1982). Petunia hybrida are predominantly propagated by cuttings and when virus-infected material is used, plantlets are also infected (Lesemann 1996). There is a low industry and consumer tolerance for viral symptoms in petunias; therefore, measures are taken to propagate from virus-free material (Lesemann 1996).

Several pathogens are commonly found in petunias, including bacteria, fungi, oomycetes, and viruses. Viruses reported in petunias include $P o$ tato virus $Y$, Tobacco mosaic virus, Impatiens necrotic spot virus, Tomato mosaic virus, Alfalfa mosaic virus, Tomato ringspot virus (ToRSV), Tobacco streak virus, Cucumber mosaic virus, Petunia vein clearing virus, and Broad bean wilt virus 1 . These viruses have been found as both single and mixed infections causing symptoms of mosaic, chlorosis, necrosis, leaf deformation, stunting, flower color breaking, and vein clearing (Lesemann 1996; Sanchez-Cuevas and Nameth 2002).

Viruses belonging to the genus Nepovirus (family Secoviridae; subfamily Comovirinae) contain nonenveloped icosahedral particles 25 to $30 \mathrm{~nm}$ in diameter that encapsidate a positive-sense, single-stranded, bipartite RNA genome. RNA1 is 7,200 to 8,400 nucleotides (nts) encoding a protease, a helicase, a genome-linked protein, and an RNA-dependent RNA polymerase (RdRp). RNA2 is 3,700 to 7,300 nt encoding the movement protein and a single coat protein of 52 to $60 \mathrm{kDa}$ in size. New species demarcation criteria includes a coat protein with less than $75 \%$ identity and conserved Pro-Pol region with less than $80 \%$ identity to described viruses (Sanfacon et al. 2012).

In 2012, Petunia hybrida cuttings that originated from South America and displayed virus-like symptoms were obtained from a commercial grower. The infected plants exhibited foliar interveinal chlorosis

Corresponding author: Dimitre Mollov;

E-mail: dimitre.mollov@ars.usda.gov

Accepted for publication 18 January 2017.

This article is in the public domain and not copyrightable. It may be freely reprinted with customary crediting of the source. The American Phytopathological Society, 2017. and mottling. The symptoms were distinct from those previously associated with viruses infecting petunia; therefore, it prompted further investigation. Here, we identified and molecularly characterized a new virus infecting petunia causing a leaf mottling disease, and determined its taxonomic relationship to other viruses. This new virus was provisionally named Petunia chlorotic mottle virus (PCMoV) and showed close similarity to members of the genus Nepovirus, subgroup A.

\section{Materials and Methods}

Virus source and transmission. Virus-infected and healthy $P$. hybrida cuttings were rooted and propagated under a mist bench and removed when roots had fully developed. Silicon carbidedusted healthy $P$. hybrida leaves were mechanically inoculated with crude sap extracts from symptomatic $P$. hybrida leaves macerated in $100 \mathrm{mM}$ phosphate buffer, $\mathrm{pH} 7.4$, containing $0.5 \%$ (v/v) 2-mercaptoethanol. Plants were kept in a greenhouse at $24^{\circ} \mathrm{C}$ in a $16 / 8$-h day/night photoperiod. Greenhouse temperature and relative humidity was logged by Onset HOBO Temperature/Relative Humidity data loggers (Onset Computer Corporation, Bourne, MA). Inoculated plants were observed weekly for symptoms, and after 4 weeks they were also examined by transmission electron microscopy (TEM) and tested by RT-PCR as described below.

Transmission electron microscopy, virion purification, and nucleic acid digestion. Symptomatic tissue was partially purified as previously described (Ahlawat et al. 1996). Partially purified extracts were examined by TEM after negative staining with $2 \%(\mathrm{w} / \mathrm{v})$ sodium phosphotungstate, $\mathrm{pH} 7.0$, containing bacitracin at $100 \mu \mathrm{g} / \mathrm{ml}$. Diameter of virions was calculated as the average of 50 measured particles.

Virions were purified from infected $P$. hybrida leaf tissue by differential centrifugation and isopycnic density-gradient centrifugation in $\mathrm{Cs}_{2} \mathrm{SO}_{4}$ as previously described (Currier and Lockhart 1996). Guanidinium thiocyanate-phenol-chloroform extraction of total particleassociated nucleic acid and nucleic acid digests were completed from purified virion particles as previously described (Chomczynski and Sacchi 1987; Lockhart 1990).

High throughput sequencing, sequence analysis, and genome assembly. Symptomatic leaves containing spherical virus-like particles were used for RNA extraction, cDNA library preparation, and whole transcriptome shotgun sequencing (RNA-Seq) as previously described (Mollov et al. 2016). The 5' ends of RNA1 and RNA2 were sequenced using 5' RACE System, v. 2.0 (ThermoFisher Scientific, Waltham, MA). Sequence-specific primers used included RNA1GSP1 (GGTAATTGCGCCCATCATAGTA), RNA2GSP1 (GAACCTCA GACATGGGAACAA), RNA1GSP2 (GGACCAACCTCAACAAC TACA), and RNA2GSP2 (CCGGCAGGATACACATTCATTA).

The $3^{\prime}$ ends were obtained using Super Script III reverse transcription (ThermoFisher) to generate cDNA using primer VdTGCR, 
$\left(\mathrm{V}(\mathrm{T}){ }_{14} \mathrm{GCCCGGGCGGCCGCG).} \mathrm{The} \mathrm{cDNA} \mathrm{was} \mathrm{purified} \mathrm{(PureLink}\right.$ PCR Purification Kit, ThermoFisher) and used in a PCR reaction (GoTaq, Promega, Madison, WI) with nested primer GCR (GCC CGGGCGGCCGCG) and sequence-specific primers RNA1For1 (GGCCCGAATGTGCTATTCTA) and RNA2For1 (CTGGAGTA ACAGCACCAGATAC) for RNA1 and RNA2, respectively. The products were separated by agarose electrophoresis, gel purified (Invitrogen PureLink Quick Gel Extraction Kit, ThermoFisher), ligated, cloned (pGEM-T Easy Vector Systems, Promega), and six individual clones per PCR product were sequenced in each direction (MCLAB, South San Francisco, CA).

The high-throughput sequencing (HTS) contigs and terminal sequences were assembled using Geneious v. 9 (Biomatters, Auckland, New Zealand) and Sequencher 5.1 (Gene Codes Corp., Ann Arbor, MI) to obtain the full viral genome.

Phylogenetic analysis. Multiple sequence alignment was performed by ClustalW (Larkin et al. 2007) using as references members of the virus subfamily Comovirinae and genus Nepovirus. The genetic relationship of the viruses was examined using the maximum-likelihood (ML) algorithm using the Molecular Evolutionary Genetic Analysis v. 7.0 (MEGA7) software (Kumar et al. 2016). Bootstrap values were generated using 1,000 puzzling steps calculated by the JTT matrix-based model (Jones et al. 1992; Saitou and Nei 1987).

RT-PCR virus detection. Primers for RT-PCR detection of both RNA1 and RNA2 were designed from the HTS contigs. The RNA1 detection primers are PCMoV_RNA1_F (ACACCACTTCACGGTC ATCC) and PCMoV_RNA1_R (CGTCTATCTCCGGCTGTGTC). Primers to detect RNA2 are PCMoV_RNA2_F (TATCCCGTCCT GACACAGGT) and PCMoV_RNA2_R (GTGAGAGCACCTCGT GGAAA). Total RNA was extracted from nonsymptomatic and symptomatic (inoculated) petunia leaves using an RNeasy Plant Mini Kit (Qiagen, Frederick, MD). A RT-PCR reaction included illustra Ready-To-Go RT-PCR Beads (GE Healthcare Life Sciences, Marlborough, MA), $10 \mathrm{mM}$ primers, and one $\mu l$ total RNA. The RT-PCR cycle consisted of: $42^{\circ} \mathrm{C}$ for $45 \mathrm{~min} ; 94^{\circ} \mathrm{C}$ for $5 \mathrm{~min}$, followed by 35 cycles of $94^{\circ} \mathrm{C}$ for $1 \mathrm{~min} ; 57^{\circ} \mathrm{C}$ for $45 \mathrm{~s} ; 72^{\circ} \mathrm{C}$ for $45 \mathrm{~s}$, and a final extension of $72^{\circ} \mathrm{C}$ for $10 \mathrm{~min}$

\section{Results and Discussion}

Virus-like disease symptoms were observed in 2012 on Petunia hybrida unrooted cuttings that originated from South America. The symptoms consisted of interveinal chlorotic leaf mottling that varied in intensity (Fig. 1). The symptoms were different from those previously reported from viral infections of petunia. Partially purified extracts from symptomatic petunia tissue were examined by TEM and numerous icosahedral virus-like particles were observed (Fig. 2). The particles had an average diameter of approximately $28 \mathrm{~nm}$. Both empty and intact virus particles were observed in extracts from symptomatic petunia tissue; no particles were observed in extracts from healthy petunia plants.

The virus was transmitted by sap inoculation from infected petunia leaves to healthy petunias. Disease symptoms similar to those observed in the source plants appeared in all inoculated plants 3 to 4 weeks postinoculation. TEM analysis showed the previously

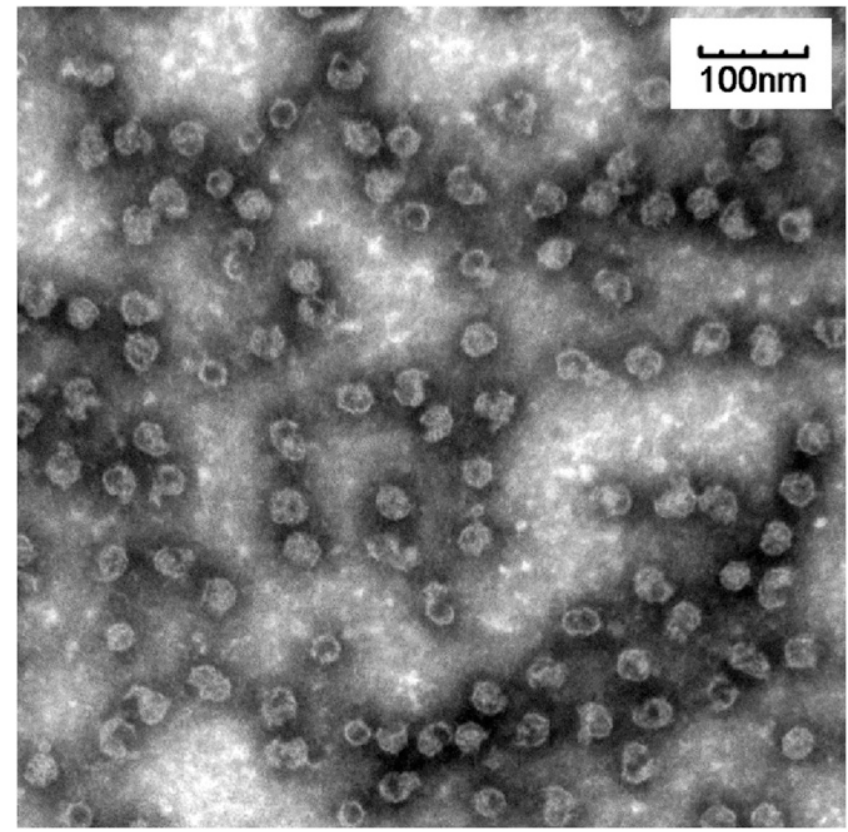

Fig. 2. Partially purified symptomatic tissue extracts stained with $2 \%$ phosphotungstic acid and observed by transmission electron microscopy at 66,000x magnification. Scale bar is $100 \mathrm{~nm}$. Numerous $28-\mathrm{nm}$ icosahedral intact and empty virus-like particles are present in symptomatic tissue.

A

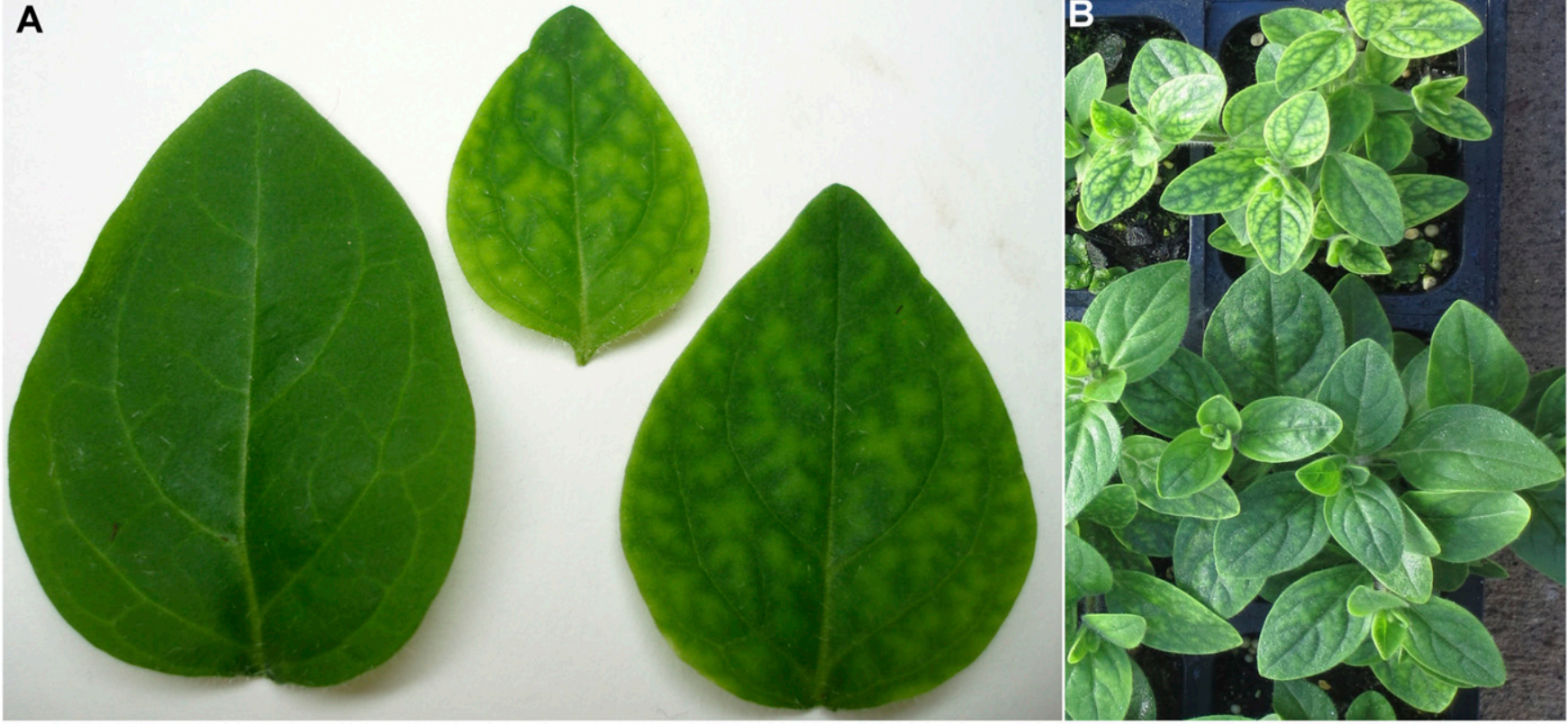

Fig. 1. Interveinal chlorotic mottling symptoms observed in Petunia hybrida. A, Left, healthy petunia leaf; middle and right, infected petunia leaves with symptoms. B, Symptoms observed in infected petunia cuttings. 
virus-free healthy plants were infected with icosahedral virus-like particles after symptoms developed. The virus was later identified by RT-PCR, thus confirming the etiology of the disease. Symptoms were reduced in severity during the summer months when

Table 1. Percentage of amino acid similarity between the amino acid sequences of the petunia chlorotic mottle virus polyprotein 1 , polyprotein 2 , Pro-Pol region (Le Gall et al. 2008), and predicted coat protein of this virus to the same regions of other respective members of the genus Nepovirus. Polyprotein 2 of PRMV is incomplete and was omitted.

\begin{tabular}{lcccr}
\hline Virus & Polyprotein 1 & Polyprotein 2 & Pro-Pol & CP \\
\hline Subgroup A & & & & \\
ArMV & 35 & 25 & 50 & 25 \\
GDeV & 38 & 23 & 51 & 23 \\
GFLV & 34 & 23 & 51 & 23 \\
RpRSV & 27 & 22 & 43 & 22 \\
TRSV & 33 & 24 & 44 & 23 \\
Subgroup B & & & & \\
BRSV & 32 & 24 & 45 & 22 \\
CNSV & 32 & 22 & 45 & 19 \\
GARSV & 33 & 25 & 47 & 23 \\
GCMV & 32 & 24 & 47 & 24 \\
TBRV & 32 & 24 & 47 & 23 \\
Subgroup C & & & & \\
BRV & 32 & 25 & 46 & 25 \\
CLRV & 31 & 21 & 42 & 21 \\
GBLV & 33 & 19 & 46 & 20 \\
PRMV & 28 & - & 40 & - \\
ToRSV & 30 & 22 & 41 & 22 \\
\hline
\end{tabular}

Name abbreviations and accession numbers: ArMV = Arabis mosaic virus (YP_053925.1, AAK07728.1); GDeV = Grapevine deformation virus (YP_006347591.1, YP_006347590.1); GFLV = Grapevine fan leaf virus (NP_619689.1, AAK07727.1); RpRSV = Raspberry ringspot virus (AAQ73822.1, AAQ73823.1); TRSV = Tobacco ringspot virus (AAQ73822.1, NP_919039.1); BRSV = Beet ringspot virus $($ NP_620112.1, NP_620113.1); CNSV = Cycas necrotic stunt virus $($ NP_620619.1, NP_620620.2), GARSV = Grapevine Anatolian ringspot virus $\left(\mathrm{YP} \_006576510.1\right.$, YP_006576511.1); GCMV = Grapevine chrome mosaic virus (NP_619705.1, NP_619704.1); TBRV = Tomato black ring virus (NP_958814.1, NP_758518.1); $\mathrm{BRV}=$ Black currant reversion virus $(\mathrm{NP}$ 612604.1, NP 612586.1); CLRV = Cherry leaf roll virus (YP_004382746.1, YP_004382747.1); PRMV = Peach rosette mosaic virus $(\mathrm{AAB} 69867.1)$; and ToRSV $=$ Tomato ringspot virus (NP_620765.1, NP_620762.1). greenhouse temperatures were between 32 to $38^{\circ} \mathrm{C}$ during the day and between 22 to $28^{\circ} \mathrm{C}$ at night.

Nucleic acids extracted from purified virus-like particles electrophoretically separated as two species (RNA1 and RNA2) of approximately 8,000 and 4,000 nt, respectively. Both fragments were completely digested by both RNaseA and mung bean nuclease but not by DNase I treatment, indicating they are components of a single-stranded RNA genome.

The HTS data consisted of 33,236,858 raw reads. These reads assembled into 332,696 contigs. A subset of 10,877 contigs longer than $500 \mathrm{nt}$ were analyzed by BLAST algorithms. Two of the contigs showed similarity to viruses of the genus Nepovirus. Over five million reads were mapped to the RNA1 contig. The RNA1 contig had an average of 66,937 depth per nt position. Similarly, 3,909,142 reads mapped to the RNA2 contig. The RNA2 contig had an average of 102,773 depth per nucleotide position. The $5^{\prime}$ and $3^{\prime}$ ends were determined using a $5^{\prime}$ RACE kit and RT-PCR using primers specific to the virus sequence and the poly-A tail, respectively.

RNA1 is 7,615 nucleotides excluding the poly A tail (deposited as GenBank Accession No. KX812815). RNA1 encodes a single open reading frame (ORF) that starts at the $5^{\prime}$ AUG (nt 115 to 118) and terminates at UAG (nt 7062 to 7065 ). The $5^{\prime}$ and $3^{\prime}$ untranslated regions are 114 and $565 \mathrm{nt}$, respectively. Analysis of the predicted amino acid sequence of RNA1 revealed conserved motifs characteristic of the RNA dependent RNA polymerase ( $R d R p)$, helicase, viral genome-linked protein, and cysteine protease of subgroup A nepoviruses. Polyprotein 1, encoded by RNA1, contains consensus motifs I through VIII conserved in the RdRp of positive-strand RNA viruses (Koonin et al. 1993). This ORF also contains the characteristic motifs for the Hel domain of picorna-like viruses belonging to the helicase superfamily III, characterized by the presence of the motif "A," "B," and "C" (Gorbalenya et al. 1990). In addition, polyprotein 1 contains the triad of conserved residues in the cysteine protease (C-Pro) region of positive-strand RNA viruses (Gorbalenya et al. 1989). The deduced polyprotein of RNA1 has a leucine (amino acid 1417) in the substrate binding pocket of protease as previously described for nepoviruses in subgroup A or B (Margis and Pinck 1992). The viral genome-linked protein (VPg) is predicted to be present between the HEL and C-Pro domains, by comparison with nepoviruses, and the conserved nepovirus VPg consensus sequence predicted by Mayoa and Fritsch was present (Mayoa and Fritsch 1994).

RNA2 is 3,804 nucleotides excluding the poly-A tail (GenBank Accession No. KX812815). RNA2 encodes a single ORF that starts at the $5^{\prime}$ AUG (nt 119 to 121) and terminates at UAG (nt 3,476 to 3,478). The
A

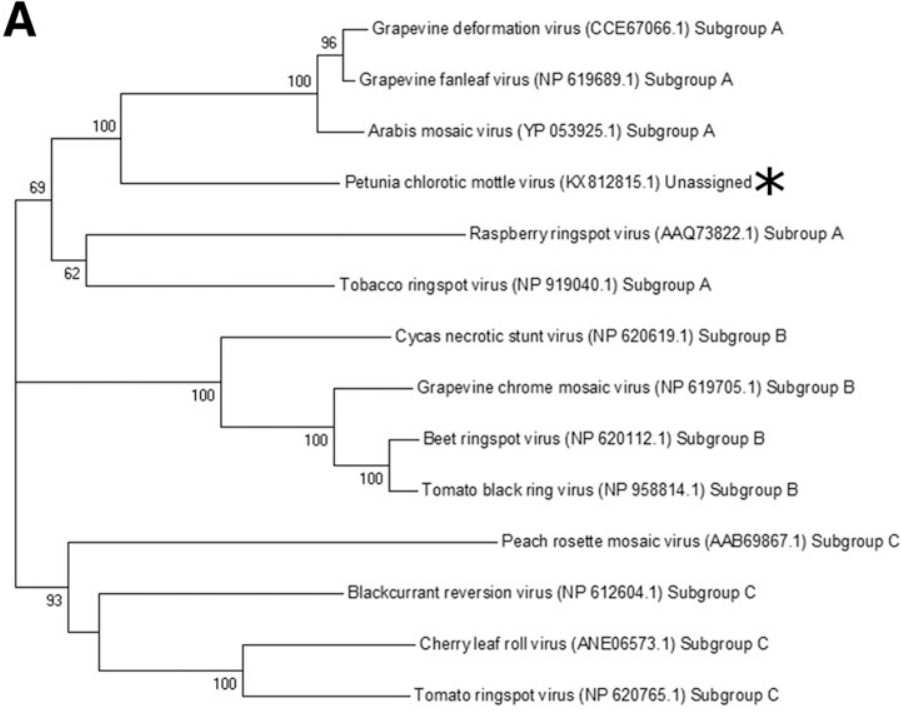

B

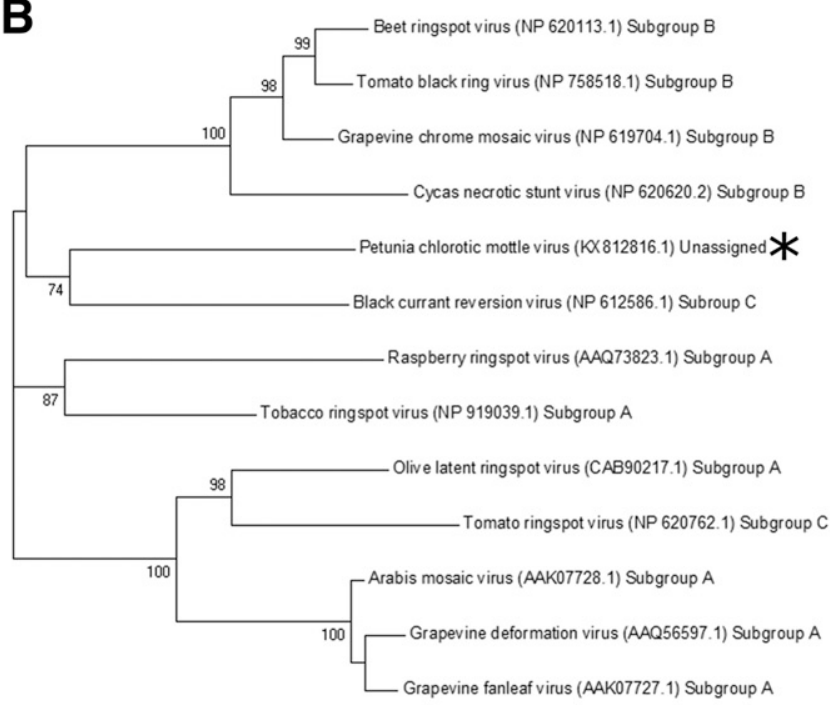

Fig. 3. Phylogenetic analysis of petunia chlorotic mottle virus, denoted with ${ }^{*}$, and selected members of the genus Nepovirus based on: A, Polyprotein 1; B, Polyprotein 2 . Phylogenetic trees were constructed using the maximum likelihood algorithm. The numerical values represent 1000 bootstrap replicate values above 50 . The scale bars correspond to substitutions per amino acid site. The accession numbers of the amino acid sequences and Nepovirus subgroup (A-C) used for analysis are listed with each virus name. 
A

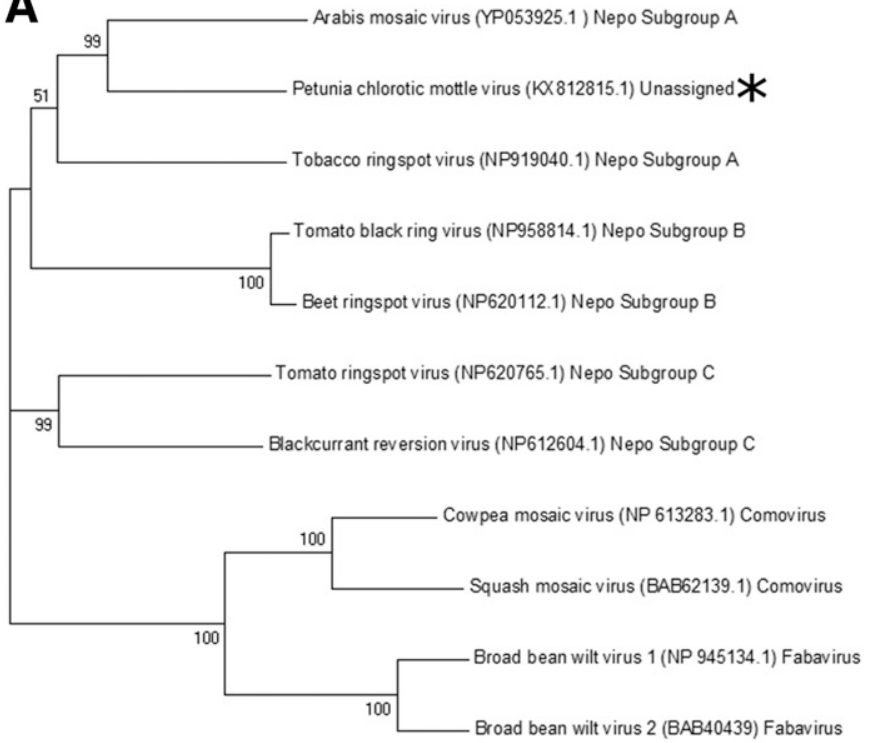

B

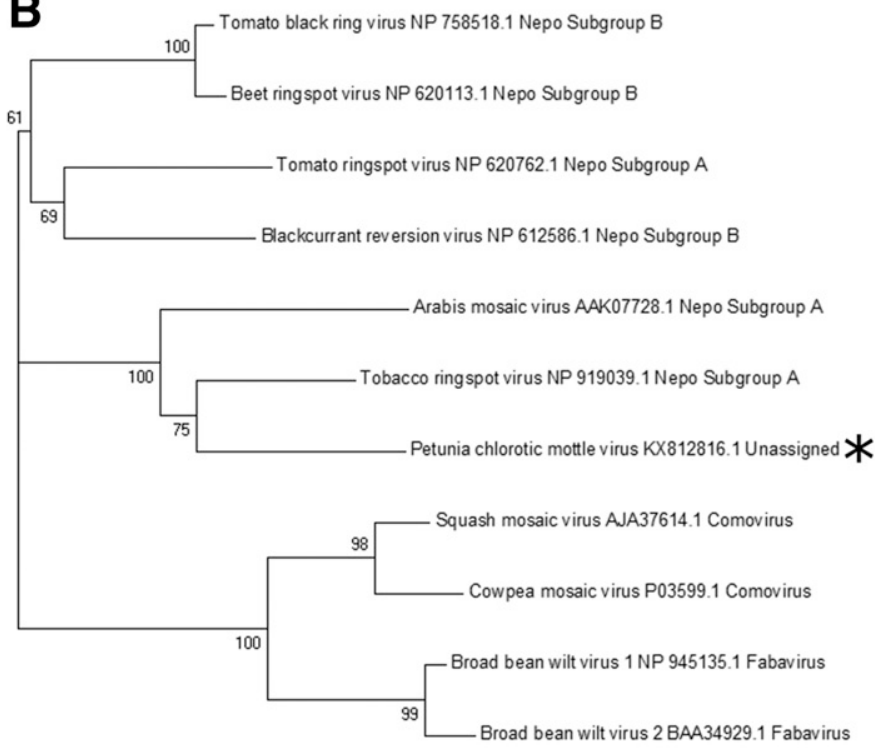

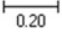

Fig. 4. Phylogenetic analysis of petunia chlorotic mottle virus, denoted with *, and selected members of the subfamily Comovirinae based on: A, Polyprotein 1 ; B, Polyprotein 2. Phylogenetic trees were constructed using the maximum likelihood algorithm. The numerical values represent 1000 bootstrap replicate values above 50 . The scale bars correspond to substitutions per amino acid site. The accession numbers of the amino acid sequences used for analysis are listed with each virus name.

$5^{\prime}$ and $3^{\prime}$ untranslated regions are 118 and 326 nts respectively. The cleavage site for polyprotein 2 between the movement protein and coat protein was predicted to be V/A based on sequence alignment with described subgroup A nepoviruses. The coat protein $(\mathrm{CP})$ is predicted to start at amino acid 852 and end at 1371 encoding a $56.7-\mathrm{kDa} \mathrm{CP}$. The CP contains the conserved nepovirus CP motif FYGR in the $\mathrm{C}$-terminus, but with a substitution from $\mathrm{R}$ to the charged amino acid D making the motif FYGD, as is observed with ToRSV (Koonin et al. 1993). The ORF also contains the LPL motif in the putative MP domain (Koonin et al. 1991).

Nepoviruses in subgroup A and B have a 3'untranslated region (UTR) of less than $1 \mathrm{~kb}$ for both RNA1 and RNA2, while subgroup $\mathrm{C}$ has a long 3' UTR of approximately $1.4 \mathrm{~kb}$ (Sanfacon et al. 2012). The 3' UTR of RNA1 of the petunia virus is 550 nt while RNA2 has a 326-nt UTR. The particle morphology, genome organization, genetic relatedness to nepoviruses, and conserved motifs all indicate the new virus is a member of the genus Nepovirus, subgroup A.

Amino acid sequence comparisons were made of polyprotein 1, polyprotein 2, the Pro-Pol region of polyprotein 1 (Le Gall et al. 2008), and the $\mathrm{CP}$ between petunia chlorotic mottle virus and nepoviruses of subgroups A, B, and C (Table 1). All regions had relatively low percent identity as is typically observed for the nepoviruses and are well below the species demarcation criteria of $75 \%$ identity for the coat protein $(<25 \%)$ and $80 \%$ for the Pro-Pol region $(<51 \%)$.

Multiple sequence alignments for polyprotein 1 and polyprotein 2 were generated using ClustalW, and the ML method was used for phylogenetic analysis. Polyprotein 1 showed close similarity to nepovirus subgroup A (Fig. 3A). Polyprotein 2 weakly aligns with a member of subgroup C (Fig. 3B). That node was supported with a bootstrap value of $74 \%$.

The genus Nepovirus (subfamily Comovirinae, family Secoviridae) has a high level of genomic diversity among its members (Sanfacon et al. 2012). To determine if the petunia virus is more closely related to other members of the Comovirinae subfamily phylogenetic trees were constructed with representative members from that family (Fig. 4). Both polyprotein 1 (Fig. 4A) and polyprotein 2 (Fig. 4B) showed the closest relationship with members of the genus Nepovirus, subgroup A.

A molecular diagnostic assay was developed for this virus. Both pairs of primers (one each for RNA1 and RNA2) amplified virus-specific targets from infected tissue, but not from healthy tissue. However, more widespread testing (more isolates and from more sources) using these primers is needed to validate the assay.

The particle morphology, genome organization, conserved motifs, and phylogenetic relationship indicate this virus is a new member of the genus Nepovirus, subgroup A. The complete genomic sequence of this virus was submitted to GenBank as Accession Nos. KX812815 and KX812816, corresponding to RNA1 and RNA2, respectively. A molecular diagnostic test has been created that can be used by diagnostic clinics to identify this virus. We propose the name petunia chlorotic mottle virus $(\mathrm{PCMoV})$ for this new nepovirus causing a leaf mottling disease in $P$. hybrida.

\section{Literature Cited}

Ahlawat, Y. S., Pant, R. P., Lockhart, B. E., Srivastava, M., Chakraborty, N. K., and Varma, A. 1996. Association of a badnavirus with citrus mosaic disease in India. Plant Dis. 80:590-592.

Bombarely, A., Moser, M., Amrad, A., Bao, M., Bapaume, L., Barry, C. S., Bliek, M., Boersma, M. R., Borghi, L., Bruggmann, R., and Bucher, M. 2016. Insight into the evolution of the Solanaceae from the parental genomes of Petunia hybrida. Nat. Plants 2:16074.

Chomczynski, P., and Sacchi, N. 1987. Single-step method of RNA isolation by acid guanidinium thiocyanate-phenol-chloroform extraction. Anal. Biochem. 162:156-159.

Currier, S., and Lockhart, B. E. 1996. Characterization of a potexvirus infecting Hosta spp. Plant Dis. 80:1040-1043.

Gorbalenya, A. E., Donchenko, A. P., Blinov, V. M., and Koonin, E. V. 1989. Cysteine proteases of positive strand RNA viruses and chymotrypsin-like serine proteases. FEBS Lett. 243:103-114.

Gorbalenya, A. E., Koonin, E. V., and Wolf, Y. I. 1990. A new superfamily of putative NTP- binding domains encoded by genomes of small DNA and RNA viruses. FEBS Lett. 262:145-148.

Jones, D. T., Taylor, W. R., and Thornton, J. M. 1992. The rapid generation of mutation data matrices from protein sequences. Comput. Appl. Biosci. 8: 275-282.

Koonin, E. V., Dolja, V. V., and Morris, T. J. 1993. Evolution and taxonomy of positive-strand RNA viruses: implications of comparative analysis of amino acid sequences. Crit. Rev. Biochem. Mol. Biol. 28:375-430.

Koonin, E. V., Mushegian, A. R., Ryabov, E. V., and Dolja, V. V. 1991. Diverse groups of plant RNA and DNA viruses share related movement proteins that may possess chaperone-like activity. J. Gen. Virol. 72:2895-2903.

Kumar, S., Stecher, G., and Tamura, K. 2016. MEGA7: Molecular Evolutionary Genetics Analysis version 7.0 for bigger datasets. Mol. Biol Evol. 33:1870-1874. 
Larkin, M. A., Blackshields, G., Brown, N. P., Chenna, R., McGettigan, P. A., McWilliam, H., Valentin, F., and Thompson, J. D. 2007. Clustal W and Clustal X version 2.0. Bioinformatics 23:2947-2948.

Le Gall, O., Christian, P., Fauquet, C. M., King, A. M., Knowles, N. J., Nakashima, N., Stanway, G., and Gorbalenya, A. E. 2008. Picornavirales, a proposed order of positive-sense single-stranded RNA viruses with a pseudo-T $=3$ virion architecture. Arch. Virol. 153:715-727.

Lesemann, D. E. 1996. Viruses recently detected in vegetatively propagated Petunia. IX International Symposium on Virus Diseases of Ornamental Plants. 432:88-95.

Lockhart, B. E. L. 1990. Evidence for a double-stranded circular DNA genome in a second group of plant viruses. Phytopathol. 80:127-131.

Margis, R., and Pinck, L. 1992. Effects of site-directed mutagenesis on the presumed catalytic triad and substrate-binding pocket of grapevine fanleaf nepovirus 24-kDa proteinase. Virology 190:884-888.

Mayoa, M. A., and Fritsch, C. 1994. A possible consensus sequence for VPg of viruses in the family Comoviridae. FEBS Lett. 354:129-130.
Mollov, D., Maroon-Lango, C., and Kuniata, L. 2016. Detection by next generation sequencing of a multi-segmented viral genome from sugarcane associated with Ramu stunt disease. Virus Genes 52:152-155.

Saitou, N., and Nei, M. 1987. The neighbor-joining method: a new method for reconstructing phylogenetic trees. Mol. Biol. Evol. 4:406-425.

Sanchez-Cuevas, M. C., and Nameth, S. G. P. 2002. Virus-associated diseases of double petunia: Frequency and distribution in Ohio greenhouses. HortScience 37:543-546.

Sanfacon, H., Iwanami, T., Karasev, A. V., van der Vlugt, R., Wellink, J., Wetzel, T., and Yoshikawa, N. 2012. Family Secoviridae. Pages 881-899 in: Virus Taxonomy: Classification and Nomenclature of Viruses: Ninth Report of the International Committee on Taxonomy of Viruses. A. M. Q. King, M. J. Adams, E. B. Carstens, and E. J. Lefkowitz, eds. Elsevier Academic Press, Waltham, MA.

van der Krol, A. R., and Immink, R. G. 2016. Secrets of the world's most popular bedding plant unlocked. Nat. Plants 2:16082.

Wijsman, H. J. W. 1982. On the inter relationships of certain species of petunia Acta Bot. Neerl. 31:477-490. 